\title{
Effect of some Antioxidants Spraying on Growth and Fruiting of Flame Seedless Grapevines
}

\author{
${ }^{*}$ El-Salhy, A.M. ${ }^{1}$; E.F. Salm ${ }^{2}$; M.M. Abada ${ }^{3}$ and Attiat M. Mostafa ${ }^{3}$
}

${ }^{1}$ Pomology Dept., Fac. Agric., Assiut Univ., Assiut, Egypt.

${ }^{2}$ Hort. Dept., Fac. of Agric. \& Natural Resources, Aswan Univ., Aswan, Egypt.

${ }^{3}$ Agricultural Research Centre, Horticultural Research Institute-Giza.

"E-Mail: abdelfattah.elsalthy@agr.aun.edu.eg

Received on: $24 / 3 / 2021$

Accepted for publication on: 30/3/2021

\section{Abstract}

This study was conducted during 2018, 2019 and 2020 seasons, on 10 years old Flame Seedless grapevines, grown on the experimental vineyard of the Research Station, Matana, Esna, Luxor, Egypt to study the effect of antioxidants on vegetative growth, nutrient status, and fruiting of Flame Seedless grapevine. The experiment was arranged in a complete randomized block design with four treatments and three replications two vine per each.

The obtained results could be summarized as follow:

Spraying either citric acid, ascorbic acid or vitamin $\mathrm{B}_{12}$ significantly increased, pruning wood weight and leaf area as well as leaf total chlorophyll and leaf nutrient composition compared to spray water ones (check treatment). No significant differences on these traits due to spray with any ones compared to either. All antioxidants treatments significantly increased the yield and improved the cluster and berry traits compared to sprayed water. It is evident from the foregoing results that spraying with either ascorbic acid or citric acid or vitamin $\mathrm{B}_{12}$ at $250 \mathrm{ppm}$ three times improved the vegetative growth, yield and berry quality.

Keywords: Antioxidants, Fruiting, Berry quality, Grapevines, Vitamin.

\section{Introduction}

Grapes are considered the first major fruit crop in its production all over the world for been nice taste, excellent flavor and high nutritional value. In Egypt, it is ranked third among fruit crops after citrus and mangoes. The total planted area attained about 221709 fed., about 1626259 tons. It is of the most important export horticultural crop and its export value is about $10 \%$ while the quantity is about $3 \%$ of total horticultural export (MALR, 2019). Flame Seedless cultivar is one of the most important commercial and early produced in Egyptian market hence it has a great importance either to local or exported markets (El-Salhy et al., 2017).

One of the goals of pomologists is to increase the production of grapes to satisfy the requirements for local consumptions and foreign markets export. The increase could be achieved by importing cultural practices i.e. fertilization, irrigation and protected cultivation of biotic and abiotic stresses (Nijjar, 1985 and Novello and de Palma, 2008).

Antioxidants play an important role in plant defense against oxidative stress induced by unfavorable conditions. Application of them is accompanied with enhancing alpha keto glutaric acid biosynthesis which is 
united with ammonia to for amino acids and proteins (Samiullah et al., 1988 and Tzeng and De Vay, 1989). Using vitamins is favourable in the biosynthesis of proteins, vitamins antioxidants enzyme and natural hormones as well as controlling diseases. They are responsible for enhancing cell division and building of most organic foods. The positive action of these antioxidants in chelating hazard radicals could results in extending the shelf-life of cells and producing healthy plants (Rao et al., 2003).

Vitamins participates a viral role in plant growth and development indirectly by enhancing the endogenous levels of various growth factors such as cytokinins and gibberellins (Foyer and Lelandias, 1993). Physiological processes such as nutrient uptake, absorption of water, translocation of organic foods, building of natural hormones, respiration, photosynthesis as well as chlorophyll and protein synthesis depend more or less on the availability of vitamins. Vitamins are known as important factors responsible for enhancing growth and fruiting of fruit crops. Vitamins have many important functions in plants. It is responsible for protecting cell walls from death and preventing reactive oxygen species (ROS) in favor of prolonging the age of cells, enhancing photosynthesis and the building of most organic foods in the plants (Samiullah et al., 1988).
The beneficial effects of antioxidants on improving the growth and nutrient status as well as yield and fruit quality were emphasized by Khrenovskov and Kameneva (2001), Ahmed et al. (2002), Ahmed and Abd El-Hameed (2004), Nashed (2006), Farahat (2008), Ahmed and SeleemBasma (2008), Abd El-Kariem (2009), Abada and Abdel-Hameed (2010), Refaai (2011), Ahmed et al. (2011), Abdelaal (2012), Abdelaal and Aly (2013), Abada (2014), Ebrahiem (2015), Abd El-Galil (2015), Mohamed-Attiat (2016), Sayed (2017) and Gamea-Marwa (2018). They found from their investigation that sprayed ascorbic acid, citric acid, and selenium were favourable to enhance the growth and fruiting of grapevines.

The aims of this investigation was testing the effect of antioxidants on growth, vine nutritional status and fruiting of Flame Seedless grapevines.

\section{Materials and Methods}

This study was carried out in three successive seasons of 2018, 2019 and 2010 on Flame Seedless grapevine. The vines were grown in the experimental vineyard of Research Station Agriculture Matana, Esna, Luxor, Egypt, where the soil is clay. Some properties of the orchard soil were determined according to Wilde et al. (1985) and are present in Table (1). 
Table 1. Some physical and chemical properties of the soil of the experiment site.

\begin{tabular}{|l|c|l|c|}
\hline \multicolumn{1}{|c|}{ Soil properties } & Values & \multicolumn{1}{c|}{ Soil properties } & Values \\
\hline Sand \% & 7.5 & Total N $(\%)$ & 0.13 \\
\hline Silt \% & 13.5 & Total $\mathrm{K}(\%)$ & 0.17 \\
\hline Clay \% & 79.0 & $\mathrm{NaHCO}_{3}$ extractable $\mathrm{P}(\mathrm{ppm})$ & 7.8 \\
\hline Texture & Clay & $\mathrm{NH}_{\mathbf{4}} \mathrm{OAC}$-extractable K $(\mathrm{ppm})$ & 463 \\
\hline $\mathrm{CaCO}_{3}(\%)$ & 1.21 & DTPA extractable $\mathrm{Fe}(\mathrm{ppm})$ & 10.75 \\
\hline Organic matter $(\%)$ & 1.35 & DTPA extractable $\mathrm{Mn}(\mathrm{ppm})$ & 12.39 \\
\hline $\mathrm{pH}(1: 1$ suspension) & 7.98 & DTPA extractable $\mathrm{Zn}(\mathrm{ppm})$ & 1.82 \\
\hline $\mathrm{ECe}\left(\mathrm{dS} / \mathrm{m}^{-1}\right)$ & 0.97 & DTPA extractable $\mathrm{Cu}(\mathrm{ppm})$ & 1.63 \\
\hline
\end{tabular}

The vines were 10 years old at the starting of this experiment and spaced at $2 \times 3$ meters apart. Twentyfour vines of healthy with no visual nutrients deficiency symptoms, nearly uniform in shape, size and productivity were chosen and devoted by this study. The chosen vines were received the usual agriculture practices that are used in the vineyard including irrigation and pest control. The vines were trained according to the T. shape system and pruned during the second week of December by leaving 15 fruiting spurs with 4 buds each plus six replacement spurs with 2 buds each.

The experiment included four treatments of antioxidants sprays as follows:

1- Spraying with distilled water (checked treatment).

2- Spraying with vitamin $\mathrm{B}_{\mathbf{1 2}}$ (V. $\mathrm{B}_{\mathbf{1 2}}$ at $250 \mathrm{ppm}$ ).

3- Spraying with citric acid at 250 ppm

4- Spraying with ascorbic acid at 250 ppm.

The experiment was set up as a complete randomized block design. Each treatment was replicated three times, two vines per each. Solution of vitamin $B_{12}$, citric acid and ascorbic acid concentrations were prepared with distilled water and then sprayed thrice after berry set, one and two months later.

Regular agricultural and horticultural practices which are used in vineyard including pruning, hoeing, fertilization, irrigation and pest control. Ammonium nitrate $(33.5 \% \mathrm{~N})$ was applied at three equal doses at growth start, after berry set and 45 days later. Potassium sulphate was added at two equal patches after berry set and one month later, where calcium superphosphate $\left(\begin{array}{lll}15.5 \% & \mathrm{P}_{2} \mathrm{O}_{5}\end{array}\right)$ was added with organic manure in the first week of January.

The following parameters were determined to evaluate the effects of different antioxidant treatments on growth, nutrient status, yield and berry quality.

\section{1- Vegetative growth Parameters:}

All vegetative growth traits i.e. main shoot thickness $(\mathrm{cm})$, number of leaves/ shoot, leaf area and total chlorophyll were measured in the middle of July.

The average leaf area $\left(\mathrm{cm}^{2}\right)$ : Twenty leaves from those opposite to basal clusters were measured according to the following equation that was reported by Ahmed and Morsy (1999)

Leaf area $=0.56\left(0.79 \mathrm{x} \mathrm{w}^{2}\right)+$ 20.01, where, $\mathrm{w}=$ the maximum leaf width. 
Weight of pruning wood $(\mathrm{kg})$ was estimated by weighing the removal one year old wood after pruning.

\section{2- Leaf nutritional status:}

Samples of 30 leaves for each replication were collected from the first full mature leaves from shoots top in mid of July and leaf petioles were separated from the blades. The petioles were washed with tap water, distilled water, air-dried, oven-dried at $70^{\circ} \mathrm{C}$ to constant weight, then ground in a stainless steel mill. Wet digestion was done by using concentrated sulphoric acid and hydrogen peroxide for overnight. Percentages of N, P and $\mathrm{K}$ (on dry weight basis) were determined in the digestion according to Wilde et al. (1985). Total chlorophylls were determined in leaves according to Von Wettstein (1957).

\section{3- Yield:}

At harvest date (mid of June), the yield per vine in terms of weight $(\mathrm{kg})$ and number of clusters per vine was recorded.

\section{4- Cluster and berry characteristic:}

Two clusters were randomly taken from each vine to determine the cluster and berry traits such as cluster weight and cluster compactness coefficient. Berry quality such as berry weight and dimension as well as reducing sugar percentages, total soluble solids and total acidity (expressed as gm tartaric acid per $100 \mathrm{ml}$ juice), berry properties were evaluated according to A.O.A.C. methods (1985). Total anthocyanin content of berry skin was determined according to Rabino and Mancinelli, 1986). All the obtained data were tabulated and analyzed according to Gomez and Go- mez (1984) and Snedecor and Cochran (1990). Differences between various treatment means were compared by Duncan's multiple range tests at $5 \%$ level of probability to Duncan (1955).

\section{Results}

\section{1- Growth vegetative characteris- tics:}

Data in Tables (2 and 3) showed the effect of antioxidants $\left(\mathrm{V} . \mathrm{B}_{12}\right.$, citric acid and ascorbic acid) on leaf area, pruning wood weight, leaf chlorophyll content and leaf mineral contents $(\mathrm{N}, \mathrm{P}, \mathrm{K})$ of Flame Seedless grapevine in 2018, 2019 and 2020 seasons. Obtained data clarified that the results took similar trend during the three studied seasons. Data in pre mentioned tables showed that sprayed either V. $\mathrm{B}_{12}$, citric acid or ascorbic acid as an antioxidant source significantly increased such traits compared to water-sprayed ones (check treatment). The maximum values of leaf area, pruning wood weight, leaf chlorophyll content and leaf mineral contents were recorded on the vines that were sprayed ascorbic acid. No significant differences were recorded due to spray with any antioxidant compared to other. On other hand, the lowest values of the growth traits were recorded on the vines that were sprayed with water (check treatment). The highest leaf area $\left(135.2 \mathrm{~cm}^{2}\right)$, pruning wood weight $(1.57 \mathrm{~kg} / \mathrm{vine})$, total chlorophyll $(5.16 \%)$, leaf $\mathrm{N}$ $(1.85 \%)$, leaf $\mathrm{P}(0.131 \%)$ and leaf $\mathrm{K}$ $(1.22 \%$ as an av. of the three studied seasons) were obtained due to spray with ascorbic acid. On other hand, the lowest values of these traits were recorded on the unsprayed $\left(119.5 \mathrm{~cm}^{2}\right.$, $1.46 \mathrm{~kg} / \mathrm{vine}, 4.63 \mathrm{mg} / \mathrm{g}, 1.80 \%$, 
$0.117 \%, 1.11 \%$ as an av. of the three studied seasons, respectively. Then, the increment percentage of leaf area, pruning wood weight, total chlorophyll and leaf NPK\% were (13.14, $7.53,11.45,9.44,11.97$ and $9.91 \%$ as an av. the three studied season) due to spray with ascorbic acid compared to the check treatment, respectively. Therefore, it could be concluded that all the antioxidant used in the vineyard have indirectly and positively effect on grapevines growth, where had a significantly increased the total leaf surface area, nutritional status and vegetative growth of vines.

Table 2. Effect of antioxidants spraying on leaf area, wood pruning weight and total chlorophyll of Flame Seedless grapevines during 2018, 2019 and 2020 seasons.

\begin{tabular}{|l|c|c|c|c|c|c|c|c|c|c|c|c|c|}
\hline \multirow{2}{*}{ Treat. } & \multicolumn{4}{|c|}{ Leaf area $\left.\mathbf{( c m}^{2}\right)$} & \multicolumn{4}{c|}{ Wood pruning weight (kg) } & \multicolumn{3}{c|}{ Total chlorophyll (mg/g F.W) } \\
\cline { 2 - 13 } & $\mathbf{2 0 1 8}$ & $\mathbf{2 0 1 9}$ & $\mathbf{2 0 2 0}$ & Mean & $\mathbf{2 0 1 8}$ & $\mathbf{2 0 1 9}$ & $\mathbf{2 0 2 0}$ & Mean & $\mathbf{2 0 1 8}$ & $\mathbf{2 0 1 9}$ & $\mathbf{2 0 2 0}$ & Mean \\
\hline Cont. & $120.3 \mathrm{~B}$ & $118.1 \mathrm{~B}$ & $120.2 \mathrm{~A}$ & 119.5 & $1.42 \mathrm{~B}$ & $1.44 \mathrm{~B}$ & $1.51 \mathrm{~B}$ & 1.46 & $4.58 \mathrm{C}$ & $4.65 \mathrm{C}$ & $4.66 \mathrm{C}$ & 4.63 \\
\hline V. $\mathbf{B}_{\mathbf{1 2}}$ & $130.1 \mathrm{~A}$ & $132.4 \mathrm{~A}$ & $134.6 \mathrm{~A}$ & 132.4 & $1.49 \mathrm{~A}$ & $1.51 \mathrm{~A}$ & $1.58 \mathrm{~A}$ & 1.53 & $4.80 \mathrm{~B}$ & $4.88 \mathrm{~B}$ & $4.90 \mathrm{~B}$ & 4.86 \\
\hline Citric A. & $131.5 \mathrm{~A}$ & $133.7 \mathrm{~A}$ & $135.9 \mathrm{~A}$ & 133.7 & $1.51 \mathrm{~A}$ & $1.53 \mathrm{~A}$ & $1.61 \mathrm{~A}$ & 1.55 & $4.93 \mathrm{AB}$ & $5.01 \mathrm{AB}$ & $5.04 \mathrm{AB}$ & 4.99 \\
\hline Ascorbic A. & $132.8 \mathrm{~A}$ & $135.3 \mathrm{~A}$ & $137.5 \mathrm{~A}$ & 135.2 & $1.53 \mathrm{~A}$ & $1.55 \mathrm{~A}$ & $1.63 \mathrm{~A}$ & 1.57 & $5.09 \mathrm{~A}$ & $5.18 \mathrm{~A}$ & $5.20 \mathrm{~A}$ & 5.16 \\
\hline
\end{tabular}

Values followed by the same letter in the same column are not significantly different at $0.5 \%$ level of probability.

Table 3. Effect of antioxidants spraying on leaf $N, P$ and $K \%$ of Flame Seedless grapevines during 2018, 2019 and 2020 seasons.

\begin{tabular}{|l|c|c|c|c|c|c|c|c|c|c|c|c|}
\hline \multirow{2}{*}{ Teason } & \multicolumn{9}{|c|}{ Treat } & \multicolumn{9}{c|}{ P \% } & \multicolumn{4}{c|}{ K \% } \\
\cline { 2 - 12 } & $\mathbf{2 0 1 8}$ & $\mathbf{2 0 1 9}$ & $\mathbf{2 0 2 0}$ & Mean & $\mathbf{2 0 1 8}$ & $\mathbf{2 0 1 9}$ & $\mathbf{2 0 2 0}$ & Mean & $\mathbf{2 0 1 8}$ & $\mathbf{2 0 1 9}$ & $\mathbf{2 0 2 0}$ & Mean \\
\hline Cont. & $1.76 \mathrm{~B}$ & $1.82 \mathrm{~B}$ & $1.82 \mathrm{~B}$ & 1.80 & $0.118 \mathrm{~B}$ & $0.116 \mathrm{~B}$ & $0.118 \mathrm{~B}$ & 0.117 & $1.11 \mathrm{~B}$ & $1.10 \mathrm{~B}$ & $1.11 \mathrm{~B}$ & 1.11 \\
\hline V. B $\mathbf{1 2}$ & $1.90 \mathrm{~A}$ & $1.93 \mathrm{~A}$ & $1.94 \mathrm{~A}$ & 1.92 & $0.130 \mathrm{~A}$ & $0.129 \mathrm{~A}$ & $0.128 \mathrm{~A}$ & 0.129 & $1.17 \mathrm{~A}$ & $1.16 \mathrm{~A}$ & $1.18 \mathrm{~A}$ & 1.17 \\
\hline Citric A. & $1.92 \mathrm{~A}$ & $1.95 \mathrm{~A}$ & $1.97 \mathrm{~A}$ & 1.95 & $0.131 \mathrm{~A}$ & $0.128 \mathrm{~A}$ & $0.130 \mathrm{~A}$ & 0.130 & $1.20 \mathrm{~A}$ & $1.19 \mathrm{~A}$ & $1.20 \mathrm{~A}$ & 1.20 \\
\hline Ascorbic A. & $1.94 \mathrm{~A}$ & $1.98 \mathrm{~A}$ & $1.99 \mathrm{~A}$ & 1.97 & $0.133 \mathrm{~A}$ & $0.130 \mathrm{~A}$ & $0.131 \mathrm{~A}$ & 0.131 & $1.22 \mathrm{~A}$ & $1.21 \mathrm{~A}$ & $1.23 \mathrm{~A}$ & 1.22 \\
\hline
\end{tabular}

Values followed by the same letter in the same column are not significantly different at $0.5 \%$ level of probability.

\section{2- Yield and cluster characteristics:}

Data presented in Tables $(4 \&$ 5 ) showed that the effect of spraying with either $\mathrm{V} . \mathrm{B}_{12}$, citric acid or ascorbic acid on yield/vine, cluster weight, berry weight, and compactness coefficient of Flame Seedless grapevine in 2018, 2019 and 2020 seasons. Spraying with V. $\mathrm{B}_{12}$, citric acid or ascorbic acid as an antioxidants source significantly increased the yield/vine and cluster weight and decreased compactness coefficient of cluster compared to water-sprayed one. Moreover, sprayed by ascorbic acid gave the heaviest yield/vine, cluster weight and berry weight and least values of compactness coefficient comparing checked treatment. The heaviest yield and cluster weight as well as berry weight and least values of cluster compactness coefficient were detected due to spray with ascorbic acid. 
The obtained highest values of yield/vine $(12.21 \mathrm{~kg})$, cluster weight $(420.3 \mathrm{~g})$, berry weight $(2.79 \mathrm{~g})$ and least cluster compactness coefficient (6.10) as an av. the three studied seasons due to spray with ascorbic acid, respectively. No significant differences were recorded due to spray with any antioxidant compared to other. Contrarily, these values on checked vines were $(10.12 \mathrm{~kg})$, (371.4 g), (2.48 g) and (6.71), respectively. Hence, the corresponding increment percentages for these traits over check treatment were $(20.65$, 13.17 and $12.50 \%$ ) as well as the decrement percentage of cluster compactness coefficient was $(9.09 \%)$ as an av. the three studied seasons, respectively. No significant differences were recorded due to spray with ascorbic acid, citric acid or $\mathrm{V}$. $\mathrm{B}_{\mathbf{1 2}}$. In general, it could be concluded that using any antioxidants had positive effects on productivity of Flame Seedless grapevines.

\section{3- Chemical constituents of berry juice:}

Data of berry characteristics as affected by different antioxidants during 2018, 2019 and 2020 seasons are presented in Tables ( $5 \& 6$ ). The data indicated that spraying with any antioxidant source significantly improved the Flame Seedless grapes quality in terms of increasing total soluble solids, reducing sugars and anthocyanin contents and decreasing total acidity compared to checked treatment. The highest total soluble solids, reducing sugars and anthocyanin contents were $(17.3 \%), \quad(15.49 \%) \quad$ and $\quad(1.32$ $\mathrm{mg} / 100 \mathrm{~g}$ ) as an av. of the three studied seasons, obtained from vines spayed with any ascorbic acid. No significant differences were recorded due to spray with antioxidant compared to others. Contrary, the least values of these traits were recorded on vines that sprayed with water (checked treatment) which gave $(15.6 \%),(14.12 \%)$ and (1.16) as an av. of the two studied seasons, respectively. Hence, the increment percentage of these attributers due to spray with ascorbic acid over the check treatment attained $(10.89 \%$, $9.70 \% \& 13.79 \%$ ), respectively. The least values of acidity was recorded on vines that spraying with ascorbic acid was $0.486 \%$ compared to $0.585 \%$ as an av. three studied seasons on checked vines. Hence, such amending induces decrement percentage in total acidity attained $(16.92 \%)$ as an av. of the three studied seasons.

Table 4. Effect of antioxidants spraying on yield/vine, cluster weight and cluster compactness coefficient of Flame Seedless grapevines during 2018, 2019 and 2020 seasons.

\begin{tabular}{|l|c|c|c|c|c|c|c|c|c|c|c|c|}
\hline \multirow{2}{*}{ Treat. } & \multicolumn{4}{|c|}{ Yield/vine (kg) } & \multicolumn{4}{c|}{ Cluster weight (g) } & \multicolumn{3}{c|}{ Cluster compactness coefficient } \\
\cline { 2 - 13 } & $\mathbf{2 0 1 8}$ & $\mathbf{2 0 1 9}$ & $\mathbf{2 0 2 0}$ & Mean & $\mathbf{2 0 1 8}$ & $\mathbf{2 0 1 9}$ & $\mathbf{2 0 2 0}$ & Mean & $\mathbf{2 0 1 8}$ & $\mathbf{2 0 1 9}$ & $\mathbf{2 0 2 0}$ & Mean \\
\hline Cont. & $8.71 \mathrm{~B}$ & $10.65 \mathrm{~B}$ & $11.00 \mathrm{~B}$ & 10.12 & $362.8 \mathrm{~B}$ & $372.0 \mathrm{~B}$ & $378.3 \mathrm{~B}$ & 371.4 & $6.72 \mathrm{~A}$ & $6.67 \mathrm{~A}$ & $6.73 \mathrm{~A}$ & 6.71 \\
\hline V. B $_{\mathbf{1 2}}$ & $9.66 \mathrm{~A}$ & $12.15 \mathrm{~A}$ & $12.55 \mathrm{~A}$ & 11.45 & $402.7 \mathrm{~A}$ & $412.0 \mathrm{~A}$ & $418.3 \mathrm{~A}$ & 411.0 & $6.48 \mathrm{~B}$ & $6.34 \mathrm{~B}$ & $6.40 \mathrm{~B}$ & 6.41 \\
\hline Citric A. & $9.76 \mathrm{~A}$ & $12.50 \mathrm{~A}$ & $12.99 \mathrm{~A}$ & 11.75 & $406.8 \mathrm{~A}$ & $417.0 \mathrm{~A}$ & $421.8 \mathrm{~A}$ & 415.2 & $6.06 \mathrm{C}$ & $6.25 \mathrm{BC}$ & $6.32 \mathrm{BC}$ & 6.21 \\
\hline Ascorbic A. & $9.76 \mathrm{~A}$ & $13.19 \mathrm{~A}$ & $13.67 \mathrm{~A}$ & 12.21 & $411.2 \mathrm{~A}$ & $422.6 \mathrm{~A}$ & $427.1 \mathrm{~A}$ & 420.3 & $6.05 \mathrm{C}$ & $6.10 \mathrm{C}$ & $6.16 \mathrm{C}$ & 6.10 \\
\hline
\end{tabular}

Values followed by the same letter in the same column are not significantly different at $0.5 \%$ level of probability. 
Table 5. Effect of antioxidants spraying on berry weight, TSS and reducing sugar of Flame Seedless grapes during 2018, 2019 and 2020 seasons.

\begin{tabular}{|l|c|c|c|c|c|c|c|c|c|c|c|c|}
\hline \multirow{2}{*}{ Treat. } & \multicolumn{4}{|c|}{ Berry weight $\mathbf{( g )}$} & \multicolumn{4}{c|}{ TSS } & \multicolumn{4}{c|}{ Reducing sugar \% } \\
\cline { 2 - 12 } & $\mathbf{2 0 1 8}$ & $\mathbf{2 0 1 9}$ & $\mathbf{2 0 2 0}$ & Mean & $\mathbf{2 0 1 8}$ & $\mathbf{2 0 1 9}$ & $\mathbf{2 0 2 0}$ & Mean & $\mathbf{2 0 1 8}$ & $\mathbf{2 0 1 9}$ & $\mathbf{2 0 2 0}$ & Mean \\
\hline Cont. & $2.44 \mathrm{~B}$ & $2.50 \mathrm{~B}$ & $2.50 \mathrm{~B}$ & 2.48 & $15.5 \mathrm{~B}$ & $15.8 \mathrm{~B}$ & $15.5 \mathrm{~B}$ & 15.6 & $14.10 \mathrm{~B}$ & $13.81 \mathrm{~B}$ & $14.45 \mathrm{~B}$ & 14.12 \\
\hline V. $\mathbf{B}_{\mathbf{1 2}}$ & $2.66 \mathrm{~A}$ & $2.73 \mathrm{~A}$ & $2.76 \mathrm{~A}$ & 2.72 & $16.9 \mathrm{~A}$ & $17.1 \mathrm{~A}$ & $16.8 \mathrm{~A}$ & 16.9 & $15.19 \mathrm{~A}$ & $14.93 \mathrm{~A}$ & $15.38 \mathrm{~A}$ & 15.17 \\
\hline Citric A. & $2.70 \mathrm{~A}$ & $2.77 \mathrm{~A}$ & $2.80 \mathrm{~A}$ & 2.76 & $17.1 \mathrm{~A}$ & $17.3 \mathrm{~A}$ & $17.0 \mathrm{~A}$ & 17.1 & $15.37 \mathrm{~A}$ & $15.11 \mathrm{~A}$ & $15.55 \mathrm{~A}$ & 15.34 \\
\hline Ascorbic A. & $2.73 \mathrm{~A}$ & $2.80 \mathrm{~A}$ & $2.83 \mathrm{~A}$ & 2.79 & $17.3 \mathrm{~A}$ & $17.5 \mathrm{~A}$ & $17.2 \mathrm{~A}$ & 17.3 & $15.51 \mathrm{~A}$ & $15.25 \mathrm{~A}$ & $15.70 \mathrm{~A}$ & 15.49 \\
\hline
\end{tabular}

Values followed by the same letter in the same column are not significantly different at $0.5 \%$ level of probability.

Table 6. Effect of antioxidants spraying on total acidity and anthocyanin (mg/100 g) of Flame Seedless grapes during 2018, 2019 and 2020 seasons.

\begin{tabular}{|l|c|c|c|c|c|c|c|c|}
\hline \multirow{2}{*}{ Treat. } & \multicolumn{5}{|c|}{ Total acidity \% } & \multicolumn{5}{c|}{ Anthocyanin (mg/100 g) } \\
\cline { 2 - 9 } Season & $\mathbf{2 0 1 8}$ & $\mathbf{2 0 1 9}$ & $\mathbf{2 0 2 0}$ & Mean & $\mathbf{2 0 1 8}$ & $\mathbf{2 0 1 9}$ & $\mathbf{2 0 2 0}$ & Mean \\
\hline Cont. & $0.612 \mathrm{~A}$ & $0.553 \mathrm{~A}$ & $0.589 \mathrm{~A}$ & 0.585 & $1.16 \mathrm{~B}$ & $1.12 \mathrm{~B}$ & $1.15 \mathrm{~B}$ & 1.16 \\
\hline V. B $_{\mathbf{1 2}}$ & $0.553 \mathrm{~B}$ & $0.506 \mathrm{~B}$ & $0.540 \mathrm{~B}$ & 0.533 & $1.26 \mathrm{~A}$ & $1.28 \mathrm{~A}$ & $1.24 \mathrm{~A}$ & 1.26 \\
\hline Citric A. & $0.526 \mathrm{BC}$ & $0.475 \mathrm{BC}$ & $0.505 \mathrm{BC}$ & 0.502 & $1.29 \mathrm{~A}$ & $1.30 \mathrm{~A}$ & $1.27 \mathrm{~A}$ & 1.29 \\
\hline Ascorbic A. & $0.509 \mathrm{C}$ & $0.459 \mathrm{C}$ & $0.491 \mathrm{C}$ & 0.486 & $1.31 \mathrm{~A}$ & $1.34 \mathrm{~A}$ & $1.30 \mathrm{~A}$ & 1.32 \\
\hline
\end{tabular}

Values followed by the same letter in the same column are not significantly different at $0.5 \%$ level of probability.

On the account of the present results, it could be concluded that spraying vines with ascorbic acid, citric acid or $\mathrm{V} . \mathrm{B}_{12}$ improved the growth and nutritional status, as well as, yield, cluster attributes and berry quality of Flame Seedless grapevines under the circumstances of this experiment.

\section{Discussion:}

Antioxidants play an important role in plant defense against oxidative stress as well as the biosynthesis of most organic foods and activation of cell division process. Ascorbic acid (vitamin c) is known as a growthregulating factor which influences many biological processes. It acts as a co-enzyme in the enzymatic reactions by which carbohydrates, proteins are metabolizes and involved in photosynthesis and respiration (Robinson,
1973). Ascorbic acid is currently considered to be a regulator on plant growth and development owing to their effects on cell division and differentiation. It is involved in a wide range of important functions as antioxidant defense, photo protection and growth (Blokhina et al., 2003).

The positive action of antioxidants in catching or chelating the free radicals which could result in extending the shelf life of plant cells and stimulating growth aspects is reported (Rao et al. 2003). In the mean time, ascorbic acid is considered a regulator of plant growth. Also, citric acid plays an essential role in signal transduction system, membrane stability and functions, activating transporter enzymes, metabolism and translocation of carbohydrates (Smirnoff, 1996). 
Antioxidants participate in plant growth and development by enhancing of natural hormones such as cytokinins and gibberellins that stimulate growth factors various physiological processes such as nutrient uptake, respiration, photosynthesis, plant pigments as well as protein and hormones biosynthesis depend on availability of antioxidants (Oretili, 1987 and Elade, 1992). Using vitamins is favourable in the biosynthesis of proteins, vitamins antioxidants enzyme and natural hormones as well as controlling diseases. They are responsible for enhancing cell division and building of most organic foods. The positive action of these antioxidants in chelating hazard radicals could results in extending the shelf-life of cells and producing healthy plants. Their positive action on controlling the incidence of pests attack did not neglect (Rao et al., 2003).

These results of the present investigation agree with those of Khrenovskov and Kameneva (2001), Ahmed et al. (2002), Ahmed and Abd El-Hameed (2004), Nashed (2006), Farahat (2008), Ahmed and SeleemBasma (2008), Abd El-Kariem (2009), Abada and Abd El-Hameed (2010), Refaai (2011), Ahmed et al. (2011), Abdelaal (2012), Abdelaal and Aly (2013), Abada (2014), Ebrahiem (2015), Abd El-Galil (2015), Mohamed-Attiat (2016), Sayed (2017) and Gamea-Marwa (2018). They found from their investigation that sprayed ascorbic acid, citric acid, and selenium were favourable to enhance the growth and fruiting of grapevines.

\section{Conclusion}

Therefore, it could be concluded that spraying with ascorbic acid citric acid or vitamin $B_{12}$ at $250 \mathrm{ppm}$ three times, improve the vine nutrient status, yield and fruit quality leading to an increase of the packable yield.

\section{References}

A.O.A.C. (1985). Association of Official Agricultural Chemists, Official Methods of Analysis A.O.A.C. Benjamin Franklin Station, Washington, D.C.M.S.A. pp: 440-512.

Abada, M.A.M. (2014). A comparative study for the effect of green tea extract and some antioxidants on Thompson Seedless grapevines. Inter. J. of Plant \& Soil Sci., 3 (10): 1333-1342.

Abada, M.A.M. and H.M. Abd ElHameed. (2010). The beneficial effects of spraying salicylic and citric acids on Flame Seedless grapevines. The sixth Inter. of Sustain. Agric. and Develop., Fac. of Agric., Fayoum Univ., 27-29 Dec., pp. 153-164.

Abd El-Galil, M.A.E. (2015). Response of Superior grapevines to spraying some antioxidant. M.Sc. Thesis, Fac. of Agric., Minia Univ., Egypt.

Abd El-Kariem, A.M. (2009). Relation of fruiting in Crimson Seedless grapevines to spraying antioxidants. M.Sc. Thesis, Fac. of Agric., Minia Univ., Egypt.

Abdelaal, A.H.M. and M.M. Aly. (2013). The synergistic effects of using turmeric with some antioxidants on growth, vine nutritional status and productivity of Ruby Seedless grapevine. Hort. Science J. of Suez Canal Univ., 1: 305-308.

Abdelaal, E.H.A. (2012). The synergistic effects of using some nutrients as well as antioxidant substances on growth, nutritional status and productivity of Thompson Seedless grown under Sohag region attempts for improving yield quanti- 
tively. Ph.D. Thesis, Fac. of Agric., Minia Univ., Egypt.

Ahmed, F.F. and H.M. Abd El-Hameed. 2004. Influence of some antioxidants on growth, vine nutritional status, yield and quality of berries in Banaty grapevines. Assiut J. Agric. Sci., 34 (4): 131-139.

Ahmed, F.F. and M. Seleem-Basma. (2008). Trails for improving yield and quality of Thompson Seedless grapes by using some antioxidants. Minia J. of Agric. Res. \& Develop., 28 (1): 1-11.

Ahmed, F.F. and M.H. Morsy (1999). A new method for measuring leaf area in different fruit crops. Minia J. of Agric. Res. \& Develop., 19: 97-105.

Ahmed, F.F.; A.M.K. Abdel-Aal; F.H. Abdelaziz and F.M. El-KadyHanaa. (2011). Productive capacity of Thompson Seedless grapevines as influenced by application of some antioxidants and nutrient treatments. Minia J. of Agric. Res. \& Develop. 31 (2): 219-232.

Ahmed, F.F.; O.H. Darwish; A.A. Gobara and A.H. Ali. (2002). Physiological studies on the effect of ascorbic and citric acids in combined with some micronutrients on Flame Seedless grapevines. Minia J. of Agric. Res. \& Develop., 22 (1): 105-114.

Blokhina, O. E. Virolainen and K.V. Fagerstedt. 2003. Antioxidant, oxidant, oxidative damage and oxygen deprivations stress, A Review Ann. Bot., 91: 179-194.

Duncan, D.B. (1955). Moldable rang and moldable F-test. Biometrics. 11: 124.

Ebrahiem, M.A.A. (2015). Response of Superior grapevines to spraying some antioxidants. M.Sc. Thesis, Fac. of Agric., Minia Univ., Egypt.

Elade, V. (1992). The use of antioxidants to control gray mould (Botrytic cinera) and white mould (Sclerotinia sclerotiorom) in various crops. Plant Pathol., 141: 417-426.

El-Salhy, A.M.; H.A. Abdel-Galil; R.A. Ibrahim; A.Y. Halim and M.K. Sayed. (2017). Effect of yeast and bio-power on growth and fruiting of Flame Seedless grapevines. Assiut J. Agric. Sci., 48 (1-1): 191201.

Farahat, I.A.M. (2008). Effect of some antioxidant and boron treatments on growth and fruiting of Red Glob grapevines. M.Sc. Thesis, Fac. of Agric., Minia Univ., Egypt.

Foyer, C.H. and S. Lelandias, S. (1993). The role of ascorbate in regulation of photosynthesis. In Yamamato, Y.; Smith, C. 11. (Ed), photosymhetic responses to the environment.

Gamea-Marwa, A.M. (2018). Effect of bio-fertilization and antioxidants on vegetative growth and fruiting of Thompson Seedless grapevines. M.Sc. Thesis, Fac. of Agric., Assiut Univ., Egypt.

Gomez, K.A. and A.A. Gomez (1984). Statistical Procedures for Agricultural Research, $2^{\text {nd }}$ Ed. Willy, New York.

Khrenovskov, E.I. and N.V. Kameneva. (2001). Effect of organic acids and titanium on the yield and quality of Pinot Grey grapes. Sadovoclstvol Vinogradarstove, No. 1, 18-19.

MALR (2019). Ministry of Agriculture and Land Reclamation Publishes. Economic Affairs Sector.

Mohamed-Attiat, A.M. (2016). Trials for alleviating the adverse effects of salinity on some grapevines cv. transplants. M.Sc. Thesis, Fac. of Agric., Minia Univ., Egypt.

Nashed, H.S. (2006). Optimal horticultural practices for the production of high quality Superior grapes. M.Sc. Thesis, Fac. of Agric., Minia Univ. 
Nijjar, G.S. (1985). Nutrition of Fruit Trees. Mrs. Usha Raji Kumar, Kilyani, New Delhia, India, pp: 206-234.

Novello, V. and L. de Palma (2008). Growing grapes under cover. Acta Hortic., 785: 353-362.

Oretili, J.J. (1987). Exogenus application of vitamins as regulators for growth and development of plants. Z. Planzenenaehr. Bodenk, 150: 375-391.

Rabino, I. and A.L. Mancinelli (1986). Light, temperature and anthocyanin production. J. Plant Physiol., 81 (3): 922-924.

Rao, M.V.; Koch, R. and Davis, K.R. (2003). Ozone a tool for probing programmed cell death in plants. Plant Mol. Biol. 44(3): 346-358.

Refaai, M.M. (2011). Productive capacity of Thompson Seedless grapevines in relation to some inorganic, organic and biofertilization as well as citric acid treatments. Ph.D. Thesis, Fac. of Agric., Minia Univ., Egypt.

Robinson, F.A. (1973). Vitamins plants. Lawrence P. Miller (Ed.) Van Nostrand Reinhold Comp. New York. Phytochemistry. Vol. 111: 195-220.
Samiullah, S.A.; M.M. Ansari and R.K. Afridi (1988). B-vitamins in relation to crop productivity. Ind. Re. Life. Sci. pp: 80-92.

Sayed, H.M.M. (2017). Effect of vine load and spraying citric acid on fruiting superior grapevines. M.Sc. thesis, Fac. of Agric., Minia Univ., Egypt, 90 p.

Smirnoff, N. (1996). The function and metabolism of ascorbic acid. Plants. Ann. Bot., 87: 661-669.

Snedecor, G.W. and W.G. Cochran. (1990). Statistical methods. $7^{\text {th }}$ ed, Iowa State Univ. Press Amer. U. S. A. 507 p.

Tzeng, D.D. and J.E. De Vay. (1989). Biocidal activity of mixtures of methionine and riboflavin against plant pathogenic fungi and bacteria and possible modes of action. Mycologia, 81: 404-412.

Von Wettstein, D.V. (1957). Chlorophyll-Letale und der submikroskopische formwechsel der plastiden. Experimental Cell Research. 12 (3): 427- 506.

Wilde, S.A.; R.B. Corey; J.G. Lyer and G.K. Voigt (1985). Soil and plant analysis for tree cultivars. Oxford, IBH, New Delhi, India, pp: 94105. 
تأثير رش مضادات الأكسدة علي نمو و إثمار كروم العنب الفليم اللابذري

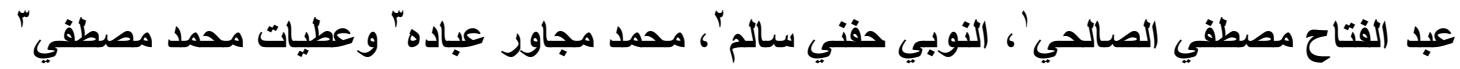

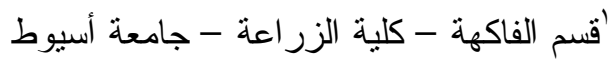

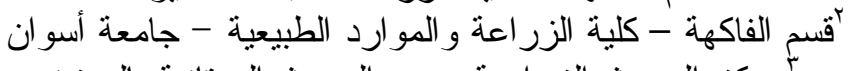

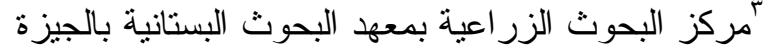

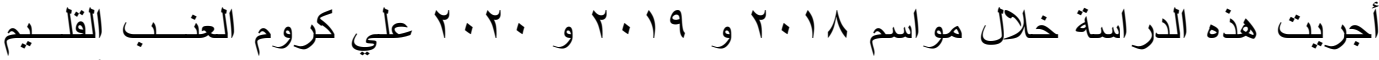

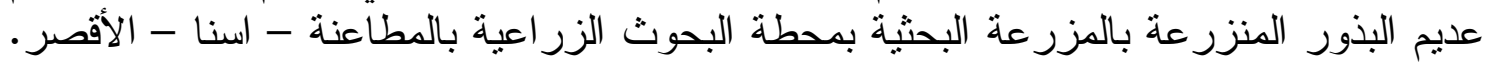

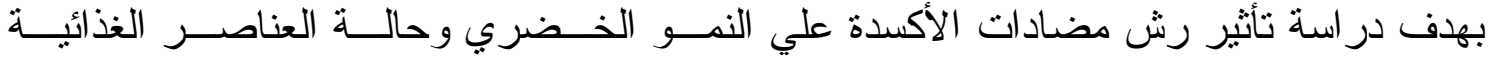
و المحصول وخصائص العناقيد و الحبات.

$$
\text { وقد أظهرت النتائج: }
$$

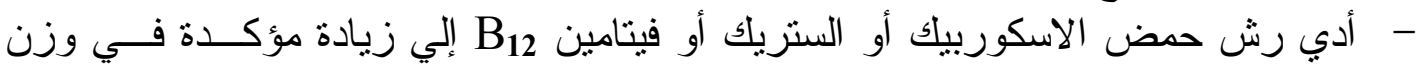

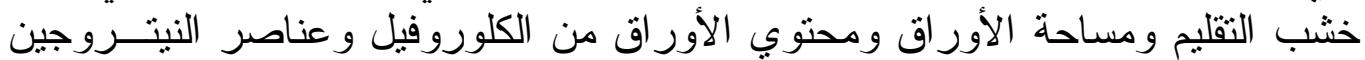
و الفوسفور و البوتاسيوم مقارنة بعدم رش مضاد مضادات الأب الأكسدة (المقارنة).

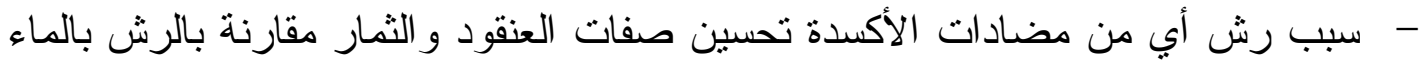
(معاملة المقارنة). - أظهرت النتائج تفوق رش مض حض الأسكوربيك مقارنة باستخدام كل من حمض الــستريك

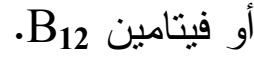

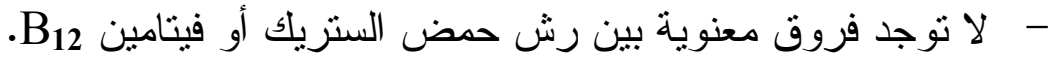

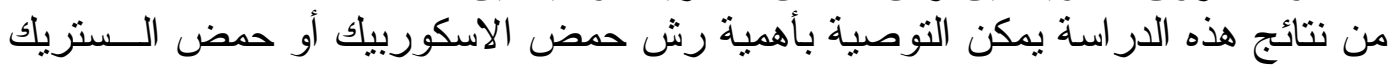

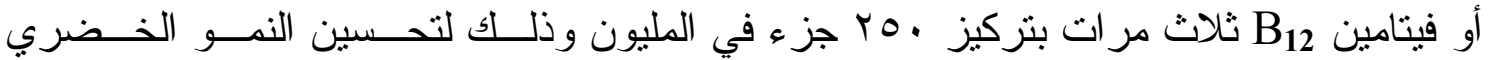

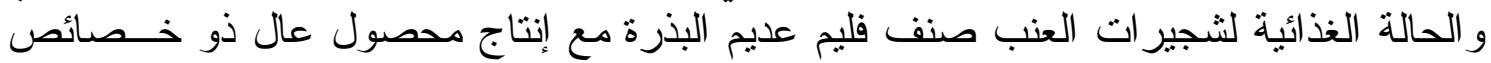
ثمرية جيدة. 